\title{
sciendo
}

DOI 10.2478/sbe-2019-0040

SBE no. 14(3) 2019

\section{WHY MICRO AND SMALL FAMILY ENTERPRISES DO NOT BORROW FROM MICROCREDIT INSTITUTIONS? A CASE STUDY IN EAST JAVA, INDONESIA}

\author{
BHUKUTH AUGENDRA \\ ITSMI Ecole de Management, Paris, France \\ TERRANY BERNARD \\ Ipag Business School, Paris, France \\ WULANDARI ANI \\ Narotama University, Surabaya, Indonesia
}

\begin{abstract}
:
It is assumed that MSMEs growth is limited due to lack of access to the financial markets, therefore MFIs play a role to refine such market imperfection. This paper aims to examine this assumption. A qualitative approach is used to obtain information from MSMEs and MFIs. Eight enterprises and three MFIs; two of them are cooperatives and one government microfinance agency are studied. There is a high demand for credit whereas not all the demand is satisfied mainly those family businesses involved in the informal sector. The main findings exhibit that even when MFIs credit is at disposal, formal and informal MSMEs prefer to draw a loan from Informal Financial Institutions (IFIs) because the market is more flexible than the MFIs which embrace the same strategies as commercial banks.
\end{abstract}

Key words: Loan, Informal Finance Institutions (IFI), Formal Financial Institutions, Family Businesses, Micro-Small Enterprises, Indonesia

\section{Introduction}

Indonesia has experienced a rapid economic growth from 1999 to 2014, averagely around $3.95 \%$ per year. Similar to most developing countries, Indonesia rests its economic development strategy on Small and Medium Enterprises (SMEs) advancement which has become a major concern during Soeharto regime in the second half of the 1990s, notably in the course of the financial and economic crisis. According to Tambunan (2014), around $96 \%$ of Indonesian labor force is employed by SMEs, operating both in the informal and formal sector (Jaswadi et al., 2015). In fact, SMEs are the biggest employment sector in Indonesia, thus its development is crucial for the economic growth of the country 
(Tambunan, 2008). The Indonesian government has implemented policies to accompany MSMEs (Bhinekawati, 2016). To sustain the development of this sector, Ministry of Cooperative and SMEs Republic of Indonesia has come with four policies:

- The first policy is to develop clusters for promoting the development of the regional product through the concept of "one village one product".

- The second policy is to encourage improvement of human resources and entrepreneurship in Indonesia.

- The third policy is to meliorate the quality and standard of a commodity produced by SMEs. The objective is to bring about a standardized product, securing halal certification and intellectual property right.

- The fourth policy consists of support for SMEs by providing funding scheme and loans at a low-interest rate through the Revolving Fund Management Agency of the Ministry.

Resolving financial issue is essential to support MSMEs growth (Tambunan, 2014). Hence, the government emanates efforts to promote microfinance to provide MSMEs access to the financial market. Thanks to the success of the Grameen Bank in Bangladesh (Yanus, 1999) and the Rakyat Bank Indonesia (RBI, 2016; World Bank, 2010; Martowijoyo, 2007), the government considers that these experiences can be replicated to enhance the development of MSMEs since Indonesia is also among the countries that host the highest number of microfinance institutions (Mulyningrum, 2007). Hence, the problem does not lie in the financial supply in the Indonesian economy, but in market accessibility and quality of product supplied (Martowijoyo, 2007). Financial institutions should be able to differentiate a start-up MSMEs from well-established ones while supplying loan to MSMEs. Family MSEs are mainly informal enterprises. We assume that these enterprises are essentially financed by the Informal Financial Institutions (IFIs) and the formal MSEs are financed by both IFIs and Formal Financial Institutions (FFIs).

In this article we are argue the reason why Micro and Small Enterprises (MSEs) prefer taking loan with the Informal Financial Institutions (IFIs). Why do the MSEs take loan with IFIs despite a high interest rate? This paper specifically addresses the issue of accessibility to the financial market. FFIs are in competition with IFIs such as moneylenders, chit funds, etc. The purpose of the research is to examine the motives of preferring IFIs, compared to the FFIs such as banks and microfinance institutions. Indeed, one wonders why family MSEs finance their investment with IFI while the FFI sector is highly developed in Indonesia. We assume that MSEs demand short-term loans to meet immediate financing needs which are satisfied by IFIs as they are more flexible than FFI. Thus, the flexibility of institutions in responding to the demand for loan is a determinant factor in the choice of institutions.

The article is organized as follows, in the next section we present the literature on microfinance institutions and access to credit market. In section 3 the research methodology is presented. We describe how the research was conducted with family MSMEs. In section 4 we present the financial market in Indonesia, in section 5 we show that there is a mismatch between demand and supply of credit in the market. This mismatch leads family MSEs to the informal credit market. In section 6 we show the 
reason why there is trade-off between formal and informal financial institutions. In section 7 we discuss the main findings of our research and conclude.

\section{Literature review}

It is assumed that SMEs are the engine of the economic growth nevertheless market imperfections and the weaknesses of institutions hinder the surge of SMEs sector (Beck and Demirguc-Kunt, 2006). The limited access to the formal financial market constitutes an obstacle to the development of SMEs both in developed and developing countries (Berger and Udell, 1998; Galindo and Schiantarelli, 2003). Berger and Udell (1998) show that the size, age, ownership, and availability of information explain financing barrier fronted by enterprises. In an economy with a high cost of transaction and asymmetric information, small enterprises demanding for small loans are less likely to obtain credit from the formal institutions. Moreover, these enterprises confront a high premium risk and they hold insufficient collateral. Beck et al. (2007) state that small businesses finance only a small share of the investment with formal sources. Consequently, they endorse a large share of the investment to the informal organization. A small-scale company has different capital structures (Berger and Udell, 1998), in which owners are employing their own financial assets (savings), bank loans and also acquire credit from the informal financial organization to start a business and to be invested in the company.

Microfinance is regarded as an institution capable of overcoming the financial market imperfection, whereas the banking sector cannot extend to all the households or individuals and SMES in an emerging economy with a low level of monetization. Access to credit market for the poor is seemed unreachable, either to smooth consumption or to endow in their business with collaterals deficiency as the main reason. A hope exists, that microfinance could flow financial services to the poor households (Bateman, 2011), allowing them to embark on a business. Microfinance institutions are practicing innovative approaches and flexible collaterals to satisfy the financial needs of unbanked individuals (Jonathan and Murdoch, 2008). Microfinance was designed to support the creation of enterprises (income generating activities) and to nurture their viability. These institutions are characterized by their utter knowledge of the poor's behavioral pattern, their capability of reducing asymmetrical information is based on trust (Yunus, 2008). Several techniques are mobilized to provide loan to people reckoned as risky or dubious by the financial institution (Gomez and Santor, 2008). Microfinance Institutions (MFIs) use group lending techniques in extremely poor communities coupled with peer monitoring (Giné and Karlan, 2008; Armendariz de Aghion and Murdoch, 2005; Anderson et al., 2002; Armendariz de Aghion and Gollier, 2000; Coleman, 1999) and also loaning to individuals (Robinson, 2001). Hapless households and MSEs, demand on modest amounts of credit reflect their economic state of affairs. A condition of which commercial banks are unable to afford, reminiscing that it is not profitable. Microfinance organizations answer the challenge by contributing a small-scale credit to conform to the aspiration of these people and to render protection against the risk of default. Furthermore, MFIs aid to higher return on investment, management aptitude enhancement, raise productivity and quality of life (Robinson, 2001). 
Those calling for a loan from MFIs are self-employed but also MSMEs (Robinson, 2001; Yunus 1999). Informal enterprises that feature pathways to financial market are commonly able to engage in a productive journey, expanding services and finally transformed into a formal organization.

The triumph of MFls has grounded on the premise that these institutions are capable of trimming down asymmetric information in the market between borrowers and lenders. It is believed that MFIs entertain a close relationship with their clients, primarily in the case of NGOs and cooperative MFIs.

The second assumption is that MFls assist in maintaining the development of MSEs. George (2005) depicts that in Tamil Nadu, India only $2 \%$ of the nascent microenterprises survived, in favor of MFIs to affirm MSEs financial limitation and foster their uprise. Nonetheless, microfinance institutions cannot prolong economic evolution of MSMEs when the loan disposed of is insufficient to support their investment. To insure against risk, microfinance institutions impose a high-interest rate, therefore the borrowers without collaterals, in demand for credit, have no other option but to take on loans with a high-interest rate. This phenomenon is generally found in MSEs, as described by Berger and Udell (1998) when firms are going mature, they postulate greater funding to finance their byplay.

Microfinance institutions are no longer able to supply financial support to MSEs as they are short on equity. Studies analyzing the impact of microfinance on poverty, development of MSEs exhibit mitigated outcomes. The performances of MFIs depend on their motivation, in this terms, profit oriented MFIs (commercial MFIs and banks) are less inclined by the objective of poverty alleviation, these institutions lend to household living above the poverty line (Karnani, 2007). Hence, Karnani (2007) questions the assumption of small enterprises' capacity to create employment. In addition, Bateman (2011) states that more and more MFIs are borrowing money to placid usage, as a result, funds are not directed toward fruitful activities, causing poor households paying high-interest rate and become indebted. Based on a study in India, Guérin et al. (2015) argues that women and lower caste people are less likely to initiate a business and even if they do, it is a small scale business. Karnani (2007) states that poor households are more susceptible to run a risk than the poorest families. Banerjee and Duflo (2011) also support this claim and present that poor households prefer to secure their life by getting involved in market paid job. They invest in innovative techniques and apply for a loan from MFIs. The study regarding access to MFIs is based on entrepreneurs living above the poverty line, who are willing to invest in their enterprises but despite the fine operations of their companies, either they fail to gain credit from MFIs or they opt to seize loans from Informal Financial Institutions (IFIs). In a highly competitive financial market, entrepreneurs have alternatives and take their decision rationally according to their interest and the market locality.

\section{Research methodology}

The research inspects various family MSMEs in East Java operating in the informal and formal sector, all of them shares something in common, which is their size. Besides, according to the World Bank, there are two kinds of individual involved in the 
informal sector, first those who are working in the informal sector as the last option of coping strategy to survive and escape from poverty. The others are individuals, entrepreneurs evolving in the informal sector to avoid paying taxes.

For this reason, we distinguish three types of companies: completely informal, entirely formal and a mix of informal and formal business. The latter characteristic relies upon the process. Some chains might be formal while the others are the opposite. Generally, the chain of production is informal, particularly in micro and small enterprises. Hence, the further an enterprise is expanding, the greater is the likelihood to become formal. They turn to be competitive and able to handle a competitive environment. At any rate, the obstruction faced by family MSEs concerning connections to the financial market, definitely constraining them to evolve, despite the financial market condition in Indonesia is highly competitive.

A qualitative research was conducted with 8 family MSMEs, 3 cooperatives, and local government. The enterprises interviewed are involved in diverse activities. The aim of the survey is to determine mutual characteristics such as access to credit market; strategies adopted to compete in a highly competitive informal and formal markets; trajectories of family businesses mainly the process through which they grow from micro to medium enterprises. The obstacles and opportunities they face to grow in a competitive market are also part of the study. The obstacles are related to access to resources, human, financial, natural resources. This article deals with the financial inclusion of micro and small family businesses in Indonesia. The sample is not representative of the overall entrepreneurship sector of Indonesia. Nevertheless, it hands out insights on MSME and it permits to comprehend its dynamism and interaction towards the financial market and also how strategies are developed by family businesses not only to survive in a competitive market but also to make profits.

Table 1 provides information on the family MSMEs interviewed, their location in East Java, Indonesia and their sizes.

Table 1: SMEs and MFIs surveyed

\begin{tabular}{|l|l|l|c|}
\hline SMEs activities & Location & Interviewee & Size \\
\hline Steel & Ngingas Village & Owner & Medium \\
\hline Batik & Madura & Owner & Small \\
\hline Cooperative (Milk) & Batu & Public Relation & Large \\
\hline Tempe Chips & Malang & Owner & Micro \\
\hline Tempe Cooperative & Malang & Manager & Large \\
\hline Fruit Candy Chips & Malang & Owner & Medium \\
\hline Statuecraft & Mojokerto & Owner & Small \\
\hline Seafood chips & Surabaya North East & Owner & Small \\
\hline PT. PNM & Surabaya & Manager & Large \\
\hline Carpenter & Pasuruan & Owner & Small \\
\hline
\end{tabular}




\begin{tabular}{|l|l|l|l|}
\hline Local government & Pasuruan & Head of Village & Large \\
\hline Bogem Syrup & Surabaya & Owner & Micro \\
\hline
\end{tabular}

The enterprises were chosen as they are known for their successes in entrepreneurship. From the information above, it could be acknowledged that the research was mainly addressed to owners of SMEs and have been operating for more than 8 years. The study concentrated on human resource management, the profitability of enterprises, financial constraints, market integration and development strategies. The typical methodology used to assess family MSMEs in East Java is a qualitative approach. The qualitative method seemed to be the most appropriate as it allows the owners to explain as much as they may about their enterprises. Their points of views were captured to figure out the way markets functioned and how it is structured, the scenario they have adapted to thrive in a highly competitive market. The owners were free to talk about the development and limitation of their firms and while discussing, a set of prepared questions were asked to guide the dialog to a certain direction, yet did not limit their responses or flow of information

Moreover, guided qualitative mechanism has one advantage it can be used to construct a quantitative questionnaire based on responses collected. An in-depth survey is time-consuming, in the sense that it requires a lot of time to review issues previously mentioned. Entrepreneurs' availability is not always extant to answer to questions. Fortunately, during the research, the owners were willing to dedicate their time throughout the whole process. The minimum time spent on the survey was 45 minutes and the longest took approximately 90 minutes, stands on the complexity and amount of information the owner delivered in answering the questions and to what extent they were keen to talk. Some were explaining their business in ease and enthusiasm, while others were less motivated.

Same questions were asked to all parties being interviewed, to compare the challenges, advantages, and opportunities for the different enterprises. In case among the contrasts there is affinity in points of difficulties, vantages, and prospects, then it will be a valuable resource to interpret the development of family MSMEs in Indonesia.

Moreover, the qualitative data was associated with secondary data available from the World Bank data base website.

\section{A competitive financial market}

As the government of Indonesia has implemented policies to promote MSMEs, the market has become more competitive. In order to develop their activities the family MSEs need financial resources. The financial market though very competitive accompanies the development MSE family business. Two types of financial institutions are distinguished: the Formal Financial Institutions (FFIs) and the Informal Financial Institutions (IFIs). 


\subsection{Characteristics of the Financial Market}

The financial market in Indonesia is highly competitive and segmented (Hamada 2010). It complies the process of liberalization since 1983. There are different financial institutions involved in the market and it is heterogeneous as it comprises three different forms of institution: formal, non-formal and informal financial institutions (Timberg, 1999). The IFIs are not registered with the local and national financial authorities who are authorized to release license in the financial market. The IFIs serve to lend capital to individuals and group of people, usually in a small amount. The FFIs are registered in the Financial Service Authority (FSA), banks are regulated through bank laws and supervised by Bank Indonesia. As for loans to individuals and MSMEs from the FFI is catered by branches of commercial banks (private and public).

Furthermore, the FSA also grants a license to individuals to operate as money lenders, brokers in the credit market, which means MSMEs and individuals have access to all the means of finance to settle their projects. These institutions (money lenders, pawn brokers, NGOs and others) intervene in the non-formal financial market. The status of these institutions is ambiguous in the sense that they are partially registered with the government institution (FSA) (Hommes et al., 2014). These institutions intervene in the market as intermediaries, linking FFIs to IFIs and formal MSEs (Timberg, 1999). Not to mentioned that these institutions are also capable of collecting deposits with the support of government and NGOs (Timberg, 1999). Non-Formal Financial Institutions are in the process of formalization, Hamada (2010) calls this process "transformation".

Micro-Finance Institutions (MFIs) are institutions registered in the FSA and are regulated by bank laws such as microfinance agencies, cooperatives, mutual funds, etc. The most popular MFI in Indonesia is Bank Rakyat Indonesia (BRI). MFIs domain varies from one another, for example, some of them have the ability to mobilize savings whereas the other cannot administer this function.

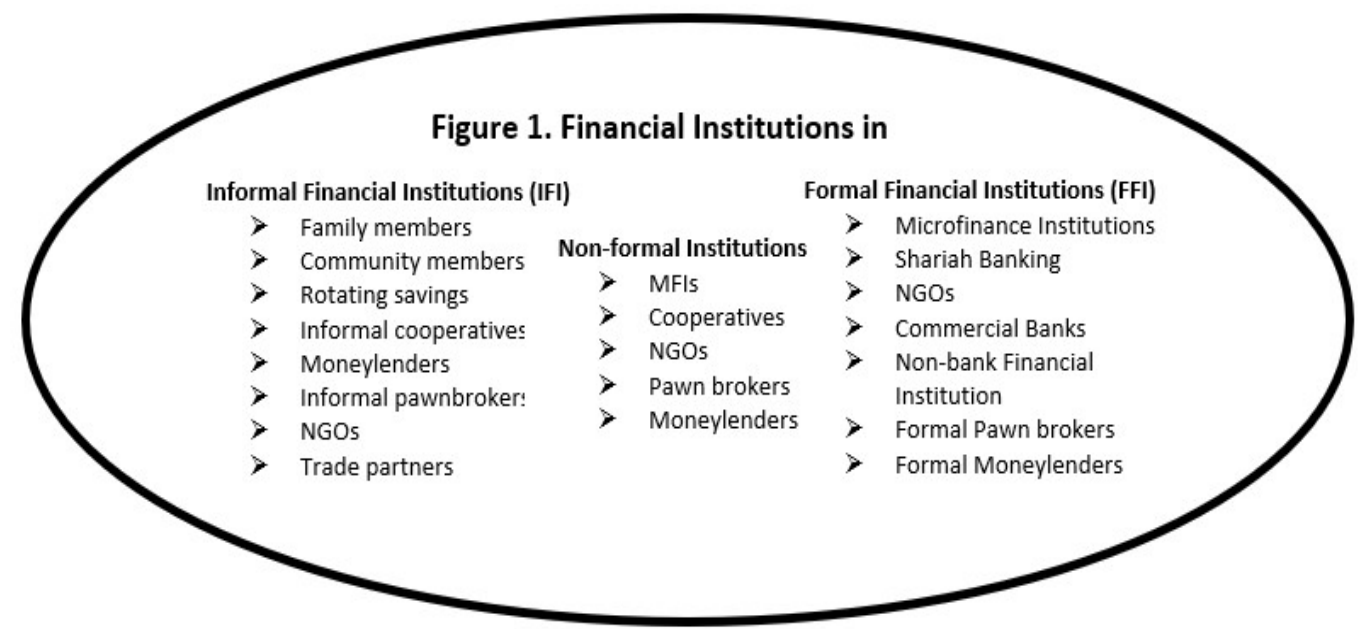


The entire aforementioned funding institutions finance individuals, households and MSMEs, obviously, competition against each other in lending small loans is inevitable, which is anchored on their capacity to mobilize provisions. For a comprehensive analysis of MFIs in Indonesia see Tambunan (2014). The paper focuses on loan lending financial institutions mainly FFIs and IFIs and analyzes access of family businesses to the financial markets. The study is based on the assumption that informal microenterprises are mainly financed by IFIs and formal family businesses have access both to IFIs and FFIs.

Firms engaging in the informal economy are unregistered, they are mainly micro and small family businesses. Consequently, these family MSEs are not subjugated to laws that bind formal firms (Lautier, 2004). According to the World Bank data only $56.2 \%$ of small firms are registered when they start the business and the percentage increases with the size of the firms. Indeed, $77.8 \%$ of medium firms and $60.8 \%$ of large enterprises are registered when they started running in the market. Therefore, small firms are more likely to get involved in the informal sector. Moreover, the family MSEs involved in the informal sector lack financial capital to develop their businesses.

\section{Table 2: Small Medium and Large Enterprises (SMLEs) relation with informality}

\begin{tabular}{|l|c|c|c|c|}
\hline Informality & Small & Medium & Large & All \\
\hline $\begin{array}{l}\text { \% of firms competing against unregistered or } \\
\text { informal firms }\end{array}$ & 68,6 & 48,0 & 69,5 & 65,0 \\
\hline $\begin{array}{l}\text { \% of firms formally registered when they started } \\
\text { operations in the country }\end{array}$ & 56,2 & 77,8 & 84,8 & 60,8 \\
\hline $\begin{array}{l}\text { Number of years firms operated without formal } \\
\text { registration }\end{array}$ & 2,3 & 1,5 & 0,7 & 2,1 \\
\hline $\begin{array}{l}\text { \% of firms identifying practices of competitors in the } \\
\text { informal sector as a major constraint }\end{array}$ & 20,0 & 17,2 & 19,2 & 19,5 \\
\hline
\end{tabular}

Source: World Bank, enterprise survey, www.worldbank.org

The data show that small firms spend 2.3 years in the informal sector before being formalized whereas medium and large firms spend respectively 1.5 and 0.7 years in the informal sector. It is clear that small firms spend more time in the informal sector than medium and large firms. Formalization depends on the profit accumulation, more reliable pathways to markets by producing superior quality products and also access to the FFIs. Entrepreneurs acknowledge this fact finely and some even put out their best efforts to invest in capital and in human resources. However, there are several issues on investment in terms of physical capital.

\subsection{Demand for Investment}

Investment in a highly competitive market depends on the demand, as the market is limited for some MSEs specially for MSEs operating in the informal economy, it is strenuous to accumulate capital and invest in the enterprise. Formal MSEs being able to accumulate profits devote their own capital in their enterprises and can also easily obtain a loan from banks and microfinance institutions (MFIs). In the cases studied, microenterprises do not have access to bank credit, thus they appeal loan from MFIs. 
In the interviews, entrepreneurs state that the profits buy them the ticket to beat off poverty, and their main action afterward is to buy house and land. They prefer investing in improving their living standard higher, rather than in their businesses which results in an inadequate fund for the enterprise sustainability. MSEs need capital for investing in purchase of raw materials, employees wages and renewing and acquiring new machines.

The retailers usually delay the payment, causing MSMEs income insufficiency to compensate employees, suppliers of raw materials who called for in cash payment. In some cases, they mobilize their private asset to cover the expenses, but when it is not enough to sustain the operation, then owners apply for a loan from banks and MFIs. MSMEs also require financial capital to enlarge physical resources to improve the productivity of the business.

MSEs claim loan from MFIs, to commence and to operate businesses but they also acquire loans from an informal financial market.

Figure 2. Activities and needs for loan

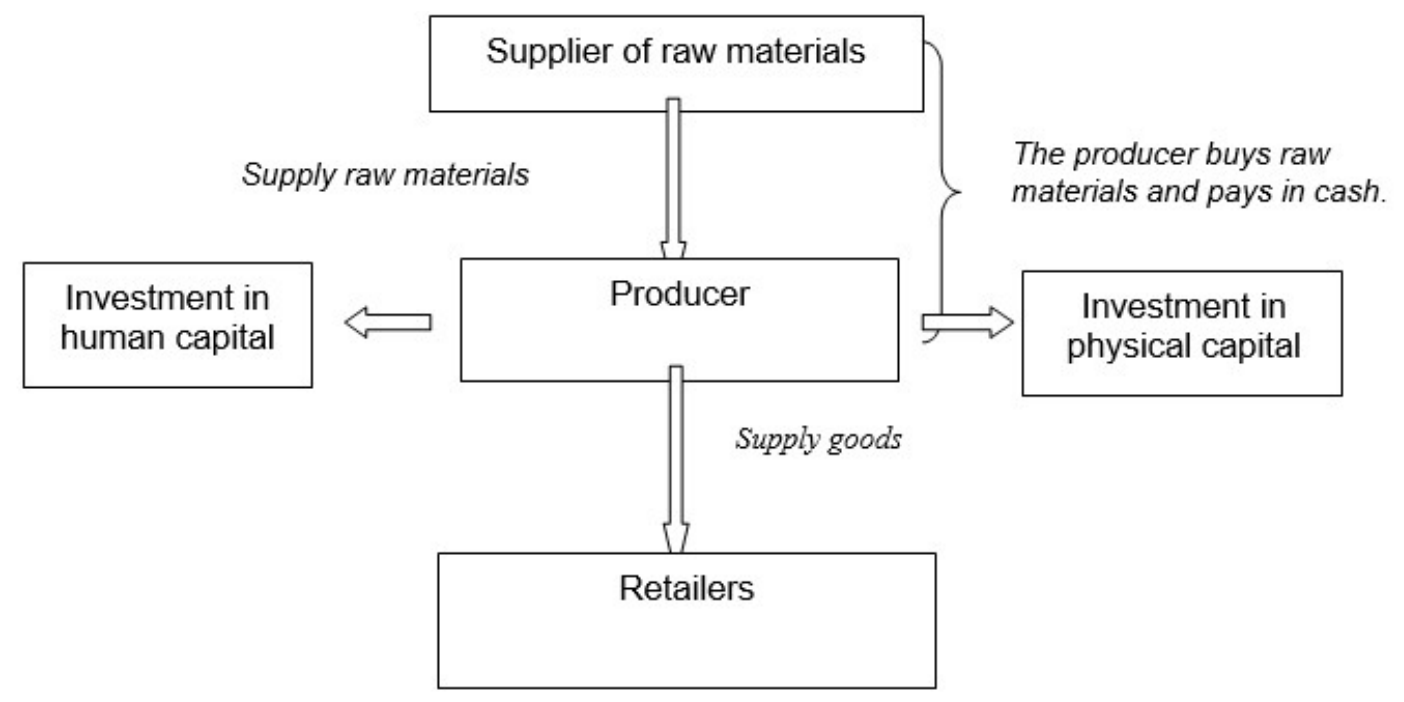

\section{Mismatch between supply and demand for loan}

Due to the aforementioned reason, MSMEs demand for a loan in the financial market exceeds the supply. MSMEs operating both in the informal and formal sector search funds to invest in their productive activities (Robinson 2001). Nevertheless, not all the demands are satisfied.

The majority of the MSEs in the informal and formal sector do not have bank accounts, making it impossible to apply for a loan from banks. The table below indicates only $55.6 \%$ of small firms possess a bank or savings account. Whereas, $96.3 \%$ of the large firms hold bank accounts. The larger the firms become, the chances of them having a bank account are more likely. Moreover, one of our findings shows that micro family businesses cannot defend their projects to the banks and MFIs to obtain a loan. This finding is 
consistent with the World Bank data showing that only $27.4 \%$ of firms in Indonesia are funded by banks. Microfinance businesses' owners have in most cases a low level of education, they often are afraid about the idea to deal with a higher educated officer who has the power to determine their business destiny.

The government of Indonesia policy is to promote MFIs to facilitate access to a loan to MSEs, in hope to match supply and demand for credit in the financial market. The government looks forward to replicating the success story of Bank Rakyat Indonesia.

\section{Table 3. Access to finance}

\begin{tabular}{|c|c|c|c|c|}
\hline & Small & Medium & Large & All \\
\hline$\%$ of firms with a checking or savings account & 55,6 & 72,6 & 96,3 & 59,3 \\
\hline$\%$ of firms with a bank loan/line of credit & 25,3 & 31,9 & 55,6 & 27,4 \\
\hline Proportion of loan requiring collateral (\%) & 82,2 & 71,3 & 92,1 & 80,4 \\
\hline $\begin{array}{l}\text { Value of Collateral needed for a loan ( } \% \text { of the loan } \\
\text { amount) }\end{array}$ & 238,6 & 253,1 & 228,3 & 241,1 \\
\hline$\%$ of firms not needing a loan & 44,6 & 37,4 & 26,4 & 42,8 \\
\hline $\begin{array}{l}\% \text { of firms whose recent loan application was } \\
\text { rejected }\end{array}$ & 0,1 & 0,2 & - & 0,1 \\
\hline$\%$ of firms using banks to finance investment & 37,0 & 36,5 & 29,7 & 36,6 \\
\hline Proportion of investment financed internally (\%) & 68,9 & 54,4 & 67,5 & 66,0 \\
\hline$\%$ of investment financed by banks & 11,6 & 17,7 & 11,4 & 12,8 \\
\hline$\%$ of investment financed by supplier credit & 1,9 & 10,3 & 4,3 & 3,7 \\
\hline
\end{tabular}

Source: World Bank, enterprise survey, www.worldbank.org

To cater that purpose, the government of Indonesia created PNM, a special MFI to finance MSMEs. Unfortunately, PNM is still unfamiliar to most of MSMEs, those who are aware of its existence are close to the local government or political parties. Only one of the entrepreneur interviewed stated having applied for a loan from PNM, he was introduced to PNM by his sister-in-law who is happened to be an employee of the local government. As a matter of fact, the others have never even heard about PNM at all, hence it appears that loan from PNM is still unreachable for MSMEs.

Another issue that prevents funding installed to MSMEs is the backbreaking administrative procedures to apply for a loan in MFIs. Family MSMEs are obliged to present a lot of documents, while in reality, a dominant number of the informal sector enterprises are not registered to the public governing body and they are not typical of administratively diligent in preserving their transaction history. The only owner having a proper and accurate business records among the entrepreneurs interviewed is the owner of fruit candy chips (fruit crispy). The rest of the entrepreneurs stated that they do not have time to maintain thorough records as it is tedious. They prefer to seek for new markets to grow their business. Nonetheless, a few MSEs manage good records of their activities when the family members are involved in the business. Furthermore, family members get specialized in some specific activity of the business, for example, the wife takes charge of the administration thus she can keep a detailed and precise record, whereas the husband takes part in productive and market penetration activities. 
The following issue that causes MSMEs unbankable is they cannot define and express clearly their business plans in front of the bank and MFIs counselors. The reason is most of the micro entrepreneurs operating in the informal sector only hold a low level of education and possess an inferiority complex, that when they are standing face to face with the FFIs officers, they found it discouraging and experiencing a hard times to understand the technical terms of banks and MFIs, eventually they fail to give a comprehensive yet convincing explanation regarding their project and so they are not funded. The entrepreneurs interviewed are not all well educated persons some of them hold a bachelor degree. Despite the level of education, dealing with FFls for loan seems difficult as they do not familiar to the process.

\section{Trade-off between ifis and ffis}

The mismatch between supply and demand for loan in the credit market leads to a trade-off between formal financial institutions and informal institutions such as moneylenders. It is undeniable fact that moneylenders throughout the world lend money at a high-interest rate, no wonder that owners of MSMEs favor informal financial institutions. This practice may look irrational but as it has been shown by Robinson (2001), poor people, MSEs are rational concerning borrowing and saving practices in developing countries. They understand how to employ the resources wisely in order to maximize their profit.

The interest rate is not a determining factor concerning a loan from moneylenders, and rational individuals would never apply for a loan at a high-interest rate. In the case of the informal economy, MSMEs are more often calling for a greater sum of a loan to invest in their businesses, which cannot be carried through by the FFIs that only distribute a small amount of credit to MSMEs since the insolvability risk is significant. Opportunity in this gap is taken by the moneylenders, who are willing to gamble with the risk and impose an interest rate above normality (Bottomley, 1963). Some entrepreneurs decided to take credit from both FFIs and IFIs to complete the budget necessary for investment in order to grow, although it is not a stable option adjusting to how much earnings they could allocate to pay off the debt.

One of the benefits of acquiring a loan from moneylenders resides on the flexibility of the IFIs. The moneylender aligns the supply to the demand, not obliging administrative procedure to obtain a loan, neither any business plan to provide to the moneylender. This finding is consistent with the study of Buckley (1997) in Africa. Even if MSMEs opt to apply for credit from the FFIs, which offer lower interest rate than IFIs, they are burdened by high transaction cost (Tsukada et al., 2010), which are time and administrative cost. MSMEs owner has to visit the FFls office and fill in the loan application, submit all document required until all complete, not to mention the time taken to wait for the whole process including a survey of applicant's house. For entrepreneur whose life depends on a day to day maintenance, time is costly. Therefore, the interest rate and the transaction costs combined, should be equal or lower than in the informal sector, or else MSMEs will take a side of the IFIs to finance their investment. 
The relationship between the moneylender and the borrower is also based on trust. The moneylender has a good knowledge of the enterprise and the owner. In addition, moneylenders also administer free administrative cost, since it is already included in the interest rate, which is the reason why the moneylender charges high of interest (Bottomley, 1963). The following factor for taking a loan from the IFIs is the proximity between moneylenders and the owners. The moneylender knows very well the owner and its capacity to reimburse the debt. Although the owner is not able to settle the debt, the moneylender cognizes that he will be compensated later. The moneylender is capable of evaluating the owner with ease and there is no way of defaulting, and if the owner does not reimburse its debt, he will be blacklisted by the IFIs. Financial constraints act as a catalyst on the owner to perform well. As long as the owner reimburses its debt, the moneylender continues to lend money, this is a depiction of how social capital shape positive externalities.

The FFIs undergo distinguished financial schemes and enterprises must fit their selection criteria to benefit from them. These institutions do not take into consideration the demand of enterprises. They believe that they could determine the best programs that will work for the enterprises, which in reality do not always suit to MSMEs necessity in the informal and formal sectors. Moreover, FFls hesitate to bear the risks by lending to MSMEs, either they lend a small amount of money or they impose a high interest which is indeed lower than what is practiced in the informal sector. This finding is also in line with another analysis in different parts of the world (Waterfield, 2008; Robinson, 2001). As a matter of fact, the difference in interest rates between the formal and informal financial institutions is not a key element in decision making.

MSMEs obtaining credit with the FFIs, usually engaged on a long term and costly debt and they have to submit some collateral to guarantee their debt that will secure the FFIs from a nonperforming loan. In contrary, moneylenders do not ask for collaterals and owners are able to bargain on the repayment of the debt. The trust relationship is strong with the moneylender rather than the FFIs that tends to be strict and stiff. MSMEs owner could lose their mortgaged assets, and negotiation with the FFIs is scarce. The importance of social capital in getting access to credit market is highlighted by Oten and Osili (2004) and also to bargain for credit and interest rate formation (Bhukuth et al., 2018).

In a competitive market, FFIs appear to be inflexible in approaching MSMEs, thus they prefer committing a loan from moneylenders despite a high-interest rate, due to its flexibility. The demand is broadly divergent that the scheme proposed using the FFls determination does not accommodate all the enterprises involved in such a competitive market.

\section{Conclusion}

Since 1983 the government of Indonesia has implemented a reform in the financial sector and formulated programs to nurture the development of MSMEs. The success of $\mathrm{BRI}$ has reinforced the view that MFIs could assist MSMEs to grow. The decision to enhance MFIs is based on the assumption that MSMEs cannot evolve due to lack of funding, therefore, providing access to credit market through microfinance will help them to 
invest in human capital and physical capital and to develop their business. Informal enterprises are mainly self-employed enterprises, they might transform into MSEs and become formalized along time.

In addition to the above assumption, there are also other premises on MSMEs inability to obtain fund from the FFIs. These presumptions are inappropriate economic and financial records, low educational level of entrepreneurs.

The study carried out in the province of East Java illustrates the obstacles in matching supply and demand for loan, despite the fact that MFIs are well established in this region. There are several factors explaining the mismatch between supply and demand for credit. The supply is not adequate to live up to the call for loan. MSMEs operate in a high contention market, in which all parties alike, require the fund to progress their business Given the limited resources, consequently MFIs apply the same strategy as commercial banks to select only riskless borrowers. One of the techniques is to adopt a complex and complicated administrative procedure and enforce a high-interest rate. The MSMEs who refuse to waste time in such routines, choose not to deal with MFIs. It happens when they have failed to respect the procedures imposed through MFIs, therefore, they opt for an alternative source of finance. These perplexed processes have a main flaw, that it is not reactive, in the sense that there is quite a disadvantaging delay in the period of time between the MSMEs loan application and the time they receive the loan because it consumes some time to complete the requirements and review the application. As a result, entrepreneurs must cover the transaction costs while dealing with MFIs in which these costs are not that expensive in total when they arrange with IFIs. For that reason, even though the interest rate is high in the informal financial sector, they prefer to gain a loan from IFIs. Moreover, the relationship between the entrepreneurs and the IFIs aid them to obtain credit without trouble, which they require fulfilling their requisites regarding investment at a specific period of time. Hence, it is not the interest rate itself which determines the choice for MSMEs decision making in terms of a loan, but the barriers to entry to the market and trust relationship.

There is a necessity to formulate a flexible MFIs programs which are able to satisfy the call for loan at the time when it is crucial to support the evolution of MSMEs. The country is very vast and with islands scattered for miles, that give rise to a problem of equity since the program cannot cut across all the territory. Some areas are marginalized by MFIs, as these institutions focus on areas where there is a numerous request for credit. In addition, not all the MSMEs are well informed about the government program, most of them are unaware about $t$ MFIs services to assist their business along with the procedures required to obtain a credit.

MSMEs also conduct a trade-off between formal and informal credit. Microenterprises prefer taking loan with moneylenders whereas SMEs prefer taking loans with banks and MFIs. MSEs are informal by nature, they require flexible approach and do not need a lot of funds to develop their activities. Whereas, medium enterprises need a lot of funds to develop. MFIs approach is considered as inflexible, not adapted to the demand of MSMEs. MFIs define arrangements without considering the real needs and difficulties faced by the MSMEs and also offer arrangement which according to the entrepreneurs are not always suitable to develop their businesses. 


\section{References}

Anderson C.L., Locker, L., \& Nugent, R. (2002). Microcredit, social capital, and common pool resources. World Development, 30(1), 95-105.

Armendariz de Aghion, B. \& Gollier. (2000). Peer group formation in an adverse selection model. Economic Journal, 110(465), 632-643.

Armendariz de Aghion, B. \& Murdoch, J. (2005). The Economics of Microfinance. Cambridge, MIT Press.

Banerjee, A.V., \& Duflo, E. (2011). Poor economics. A radical rethinking of the way to fight global poverty. Public Affair, 2011.

Bateman, M. (2011). Microfinance as a development and poverty reduction policy: Is it everything it's cracked up to be?. Background Note, ODI, 2011.

Bateman, M., \& Chang, H.J. (2012). The microfinance and the illusion of development: From Hubris to Nemesis in thirty years. World Economic Review, 1(2012), 13-36.

Beck, T., \& Demirguc-Kunt, A. (2006). Small and medium-size enterprises: Access to finance as a growth constraint. Journal of Banking and Finance, 30(11), 2931-2943 .

Beck, T., A., Demirguc-Kunt, A., \& Levine, R. (2007). Finance, inequality and the poor. Journal of Economic Growth, 12(1), 27-49.

Berger A.N., \& Udell. G.F. (1998). The economics of small business finance: The roles of private equity and the debt markets in the financial growth cycle. Journal of Banking \& Finance, 22(6-8), 613-673.

Bhukuth, A., Ballet, J., \& Radja, K. (2018). An analysis of social proximity and interest rate in rural South India. Economics and Sociology, 11(1).

Bottomley. (1963). The premium for risk as a determinant of interest rate in undeveloped rural areas. Quaterly Journal of Economics, 77(4), 637-647.

Buckley, G. (1997). Microfinance in Africa: Is it either the problem or the Solution?. World Development, 27(7), 1081-1093.

Coleman, B. (1999). The impact of group lending in Northeast Thailand. Journal of Development Economics, 60,105-41.

Don Johnston, Jr. \& Murdoch, J. (2008). The unbanked: Evidence from Indonesia. The World Bank Economic Review, 22(3), 517-537.

Galindo, A., \& Schiantarelli, F. (2003). Credit Constraints and Investment in Latin America. RES Working Paper 4305, Inter-American Development Bank, Washington D.C.

George, A. (2005). India Untouched: The Forgotten Face of Rural Poverty. Writer's Collective

Ghatak, M. (1999). Group lending, local information and peer selection. Journal of Development Economics, 60(1999), 27-50.

Giné, X., \& Karlan, D.S. (2008). Peer monitoring and enforcement: Long term evidence from microcredit lending groups with and without group liability. World Bank, January 2008.

Gomez, R., \& Santor, E. (2008). Does the microfinance lending model actually work?. The Whitehead Journal of Diplomacy and International Relations, Winter/Fall, 2008, 37-56.

Guérin, I., D’Espallier, B., \& Venkatasubramanian, G. (2015). The social regulation of markets. Why microfinance fails to promote jobs in rural South India?. Development and Change, 46(6), $1277-1301$.

Guérin, I., \& Kumar, S. (2007). Clientélisme, courtage et gestion de risque en microfinance. Etude de cas en Inde du Sud. Autrepart, 2007/4 (44), 13-26.

Hamada, M. (2010). Commercialization of Microfinance in Indonesia: The Shortage of Funds and the Linkage Program. The Developing Economies, 48(1), 156-176. 
Hommes, M., Khan, A., Gerber, C., Kipnis, H., \& Hamm, K. (2014). Out of the shadows and into the banks: Financing very small and informal enterprises. Enterprise Development and Microfinance, 25(3), 212-225.

Jaswadi, Mohammad lqbal, Sumiadji. (2015). SME governance in Indonesia - A survey and insight from private companies. Procedia in Economics and Finance, 31(2015), 387-398.

Karnani, A. (2007). Microfinance misses its marks. Stanford Social Innovation Review, Summer 2007.

Lederwood, J. (2000). Sustainable banking with the poor. Microfinance handbook. An institutional and financial perspective. The World Bank, Washington DC.

Martowijoyo, S. (2007). Indonesian Microfinance at the Crossroads. Caught between Popular and Populist Policies. Essays on Regulation and Supervision No23.

Morduch, J. (2000). The microfinance schism. World Development, 28(4), 617-629.

Mulyaningrum. (2007). The Role of the Rakyat Bank Indonesia (RBI) in strengthen Small and Medium Enterprises (SME). Conference Paper, Institute of Technology Management and Entrepreneurship, 28 July 2007.

Okten, C., \& Osili, U.O. (2004). Social networks and credit access in Indonesia. World Development, 32(7), 1225-1246.

Rakyat Bank Indonesia (RBI). (2016). Contributing to the Nation: Developing Leading MSMEs in the Digital Era. RBI Report, 2016.

Robinson M.S. (2001). The microfinance revolution: sustainable finance for the poor. The International Bank for Reconstruction and Development/World Bank, 2001.

Tambunan, T. (2014). The importance of microfinance for development of MSMEs in ASEAN: evidence from Indonesia. Journal of ASEAN Studies, 2014(2), 80-102.

Tambunan, T. (2008). SME development in Indonesia: do economic growth and government supports matter?., IJAPS, 4(2), 111-133.

Timberg, (1999). Small and micro-enterprise finance in Indonesia: what do we know?. Agency for International Development, 18 August 1999.

Tsukada, K., Higashikata, T., \& Takahashi. K. (2010). Microfinance penetration and its influences on credit choice in Indonesia: evidence from a household panel survey. The Developing Economies, 48(1), 102-127

Waterfield, C. (2008). Explanation of Compartamos Interest Rate, microfinancetransparency.com.

World Bank, enterprise survey, www.worldbank.org

World Bank. (2010). Improving Access to Financial Services in Indonesia. World Bank, No.52032, Jakarta, Indonesia.

Yunus, M. (2008). Creating a World without Poverty: Social Business and the future of Capitalism.

Yunus, M. (1999). Banker to the Poor: The Story of the Grameen Bank. London Aurum Press, pp313 